\title{
Prevalence of drug resistance mutations in HIV-1 protease gene from North India
}

\author{
Mohd Azam ${ }^{1,2^{*}}$, Abida Malik ${ }^{1}$ Meher Rizvi', Supriya Singh², Hanu Ram², Megha Singhal², Poonam Gupta ${ }^{2}$ \\ From First International Science Symposium on HIV and Infectious Diseases (HIV SCIENCE 2012) \\ Chennai, India. 20-22 January 2012
}

\section{Background}

Success of combination ART therapy in treating HIV infection is hampered due to emergence of drug resistant mutations in polymerase gene. The present study was conducted to find out the prevalence of drug resistance-conferring mutations in protease gene in HIV-1 infected patients.

\section{Methodology}

CD4 cells estimation was done in all patients. The protease gene was amplified from pro-viral DNA by nested PCR and then sequenced. Mutational analysis and subtyping were done by using Stanford database and REGA HIV-1 subtyping tool, respectively.

\section{Results}

Among 35 patients, there were 17 drug naïve and 18 first line drugs experienced HIV-1 infected patients (22 males \& 13 females; mean age: 35.95 years; mean CD4 cells: 216.4 cells $\left./ \mathrm{mm}^{3}\right)$. Majority of our patients showed mutations at T12S/T (82.85\%), K14R (40\%), I15V (71.42\%), L19I/T/V/M (97.14\%), M36I (71.42\%), R41K (88.57\%), L63P (65.71\%), H63K (100\%) and L89M (74.28\%) positions in both group of patients while other mutations were at positions $35,37,45,60,62,77$, and 82 in few cases. Interestingly, one first line drug experienced patient showed major DR mutations at D30N and M46I positions. Majority (94.28\%) was belonging to subtype C and 2 patients were belonging to subtypes A (A1).

\section{Conclusion}

HIV-1 subtype $C$ predominates in northern India followed by subtype A. Major DR mutation M46I are

\footnotetext{
* Correspondence: mdazam25@gmail.com

'Department of Microbiology, J. N. Medical College, Aligarh Muslim University, Aligarh, India

Full list of author information is available at the end of the article
}

suggested to confer low levels of resistance to ATV, FPV, IDV, LPV, NFV and TPV.D30N confers resistance only to NFV. Resistance testing in HIV-1 infected patients should be performed before the initiation of therapy for better therapeutic outcome.

\section{Author details}

${ }^{1}$ Department of Microbiology, J. N. Medical College, Aligarh Muslim University, Aligarh, India. ${ }^{2}$ Division of Biochemistry \& Biotechnology, National Centre for Disease Control, New Delhi, India.

Published: 4 May 2012

doi:10.1186/1471-2334-12-S1-P84

Cite this article as: Azam et al:: Prevalence of drug resistance mutations in HIV-1 protease gene from North India. BMC Infectious Diseases 201212 (Suppl 1):P84
Submit your next manuscript to BioMed Central and take full advantage of:

- Convenient online submission

- Thorough peer review

- No space constraints or color figure charges

- Immediate publication on acceptance

- Inclusion in PubMed, CAS, Scopus and Google Scholar

- Research which is freely available for redistribution

Submit your manuscript at www.biomedcentral.com/submit
C Bïomed Central

\section{Biomed Central}

